\title{
FOREST TREE-PLANTING ON THE IOWA PRAIRIES.
}

\begin{abstract}
ESSRS. Hall and Whitney, in their geological sur-
12. vey of lowa, state that forest trees will not grow \%or on the prairies; that the soil was formed by the d. subsidence of water, and, as such, will not sustain of forest trees, thus adopting the water theory of prairie forf mations. Now any old settler in Iowa can confute all ई this theorizing by experience and observation, and can \{ prove the fire theory as the true one of prairie formation, and that trees of all sorts will grow on the prairies of Iowa, as well as in the timberland.
\end{abstract}

Mr. Azariah Pinney, about four miles east-by-south of Iowa City, as long ago as Duncan \& Jerome printed the Repubtican, expressed to them, with much indignation, the confutation of Hall's statement. He thought it injurious to the settlement of the prairies. In 1850 he planted the seeds of burr-oaks which are now, some of them, over a foot and a half through. He transplanted white oak, hickory, black walnut, white ash, black (or basket) ash, red and white elm trees, many white elms coming up of themselves - the largest elm came up of itself. Wild cherries came up of themselves, and also choke-cherries. He transplanted a large soft maple and a few catalpas, not succeeding very well, the winter being too severe for catalpas. He cut down seven cotton-wood trees that were drinking up the well of water. After this the house-well gave plenty of water. The largest cotton-wood was two and a half feet through at the butt, and one of these measured seventy-five feet high. As evidence of the trees drawing water out of the well, he found water near the roots of the cotton-wood coming to the surface. He sank the well four feet, and, as the trees grew, the well went dry. Before, all his stock and the neighbors' was watered at the well, and the railroad and others hauled water by the barrel. But the grove, now at a distance, conducts water to the well, and helps it, much more stock being on the place and watered at it. 
He also planted about a quarter of an acre of yellow Whlocust seed, and the first year some few scattering trees were three feet high, but the winter snow broke them down. He dug up the scattering locusts and put them in one row, and manifold more came up from the roots cut off, and formed a large grove of trees. He sold $\$ 200$ worth of trees and used $\$ 100$ worth of posts, poles, and wood, after the borers began to kill the trees. One string of fence entirely of poles was about fifty rods long. There are now one hundred feet of shedding made of the posts and poles of these locusts.

He has succeeded in raising about fifty rods of willow fence that will turn cattle. One cotton-wood stock-fence, that the fire ran through, yielded some forty cords of the best wood. Thus much for the confutation of Hall's theory. Osage orange hedge was mostly a failure, although some fifty rods, out of two miles around the farm, grew well. Eighty dollar's worth of locust trees were set in the State House yard, now the University campus, and all died by borers.

\section{EDITORIAL NOTES.}

We wish our readers a Happy New Year.

ANy defeets in this issue may be set to the want of usual sight to revise copy.

THE article on Forest Tree Planting in our Prairies, is by a practieal farmer, and it deserves the attention of all agriculturists.

THE Rock Island railway is extensively advertised and illustrated in this first publication of 1883 . Other railroads will be treated in the same manner, when they furnish the Editor similar accommodations and facilities of travel.

Tre Editor, being under the care of Prof. Hobby of the State University, for defective sight, and also taking counsel of Dr. Henry Foster, of Clifton Springs, N. Y., is obliged to devolve much labor on his Associate Editor, Judge A. R. Fulton, of Des Moines, as Corresponding Editor. No man in the State is better qualified to aid in this work. He is editing two hundred insides for as many newspapers every week. Already he has contributed several articles that have been widely copied and credited to the Anvals. 
Copyright of Annals of Iowa is the property of State of Iowa, by \& through the State Historical Society of Iowa and its content may not be copied or emailed to multiple sites or posted to a listserv without the copyright holder's express written permission. However, users may print, download, or email articles for individual use. 